\title{
Recent Research Trends on Jurchen-Manchu Studies in Korea
}

Noh Kishik*

\section{Introduction: Manchus and Manchuria in Korean History and Historiography}

Koreans originated from Manchuria and had established a number of states there in ancient times. Manchuria was also the main route connecting Korean and Han Chinese states in the premodern period. People in the Korean peninsula and Manchuria interacted continuously throughout history. Manchuria was often the prize in numerous clashes between the Han Chinese and nomadic peoples.

For the northern Asiatic peoples, Manchuria was their home whereas for the Chinese the place was a strategic base to defend against foreign incursions. Whoever controlled Manchuria often held an advantageous position. Throughout history, Korean states had to make a difficult choice in these conflicts, sometimes on their own initiatives, but often the choice was forced upon them from the outside. When Manchuria became the main arena of imperialist struggles in the ninteenth century, Korea was again caught in the vortex. Due to its geographic proximity and historical connections, Manchuria and its peoples have been significant influences in Korean history. Moreover, there exist linguistic affinity and a shared culture between Korea and Manchuria. It is not surprising that Manchuria

* Senior Researcher, Northeast Asian History Foundation 
and its history have been studied extensively by Korean scholars of various disciplines. This short review article will introduce recent Korean research trends on Manchu history of the period when the Jurchen tribes were unified and then established the Qing that ruled over all of China.

\section{Studies on Korea-Jurchen Relations in the Early Chosŏn}

In the latter half of the fourteenth century, there were dynastic changes from the Yuan to the Ming in China and from Koryŏ to Chosŏn in Korea. The Jurchens in Manchuria finally escaped from Mongol rule at the time, but the new Chosŏn dynasty in Korea tried to control the Jurchen tribes in its efforts to strengthen the northern border. Moreover, the rapid rapprochement between Chosŏn and the Ming was a result of their attempt to form a united front against the Mongol threat. The issue of the northern border is one of the major topics in the study of early Chosorn history, and there has been considerable amount of research since the 1950s. They are mostly based on analysis of the entries dealing with the Jurchens in the Chosŏn wangjo sillok (朝鮮王朝實錄, Veritable Records of the Chosŏn Dynasty).

There are a number of studies on the formation of the northern border and defense system in the early years of the dynasty. There were detailed studies on the establishment and abolition of the Four Commanderies (四 郡) in the upper Amnok [Yalu] region, the Six Military Commands (六鈚) on the northern border, policies to resettle and populate the border region, and the construction of defense installations, etc. ${ }^{1}$

There is also research on the Chosŏn court's Jurchen policy. Chosŏn adopted a policy of appeasement as it followed the principle of "serving the great and neighborly relations (事大交隣)." Chosŏn “served" the Ming and maintained neighborly relations with the Jurchen tribal leaders and Japanese military rulers. Chosŏn also employed a strategy of incorporating Jurchens within its sphere of influence by bestowing official ranks to tribal leaders. Jurchens came to the Chosŏn court at least 
1,098 times on tribute missions. The court granted generous gifts in return, and gave permission to purchase supplies by establishing trading posts. There are detailed studies on Jurchens who settled in Korea as refugees and served as royal guards. ${ }^{2}$

In the past few years, young scholars Han Sŏngju ${ }^{3}$ and Pak Chŏngmin ${ }^{4}$ have continued research on the Jurchens during the early Chosonn period. Nam Üihyŏn's work focused on Ming policy toward the Jurchens through his study of the Liaodong Regional Military Commission. ${ }^{5}$ Pak Wŏnho published a book that looked into Chosŏn-Ming relations revolving around the Jurchen issues. ${ }^{6}$ Another scholar reviewed previous research and called for new approaches. ${ }^{7}$

\section{Broader Perspectives on the Manchu Invasions: War and the East Asian International Order}

The second research trend is the "boom" in the study of the two Manchu invasions of Korea in the early seventeenth century. Korean scholars tended to focus on resistance against the Manchu invasions of 1627 and 1636, and we initially had relatively few studies as there had been a tendency to avoid "the shameful history." Yu Chaesŏng's work on the background, causes, development, and consequence of the invasions

1 Ch'a Yonggŏl, "4-gun 6-chin ŭi kaech'ŏk," Han'guksa 22 (Kuksa P'yŏnch'an Wiwŏnhoe, 2003).

2 Kim Kujin, "Yŏjin kwa ŭi kwan'gye," Han'guksa 22 (Kuksa P'yŏnch'an Wiwŏnhoe, 2003).

3 Han Sŏngju, Chosŏn chŏn'gi sujik Yŏjinin yŏn'gu (Kyŏngin Munhwasa, 2011).

4 Pak Chŏngmin, Chosŏn sidae Yŏjinin naejo yŏn'gu (Kyŏngin Munhwasa, 2015).

5 Nam Ǔihyŏn, Myŏngdae Yodong chibae chŏngch'aek yŏn'gu (Ch'unch'ŏn: Kangwŏn Taehakkyo Ch'ulp'anbu, 2008).

6 Pak Wŏnho, Myŏngch'o Chosŏn kwan'gyesa yŏn'gu (Ilchogak, 2002).

7 Chŏng Taham, “'Sadae' wa 'kyorin' kwa 'Sojunghwa' ranŭn ch'o sigan chŏgin kŭrigo ch’o konggan chŏgin maengnak,” Han'guk sahakpo 42 (2011). 
from the perspective of resistance represents a culmination of the earlier works. $^{8}$

More recently, there has been an effort to approach the wars from the framework of East Asian interstate relations. This can be seen in the works of Ch'oe Soja ${ }^{9}$ and Kim Chongwŏn ${ }^{10}$ in the 1970s. There are works that analyzed wars on the Korean peninsula within the context of the long history of East Asian interstate relations. ${ }^{11}$ Han Myŏnggi tried to reinterpret the Hideyoshi Invasion of 1592 as a greater East Asian war, and he continued with the reconsideration of the Manchu invasions of Korea in the greater context of East Asian interstate relations.

We have also witnessed several popular films and novels based on the Manchu invasions. Han also produced a popular book that compared geopolitical situations of the seventeenth century Chosorn to the twenty first century Korea between the G2 [the United States and China]. ${ }^{12}$ The

8 Yu Chaesŏng, Pyŏngja horansa (Kukpangbu Chŏnsa P'yŏnch'an Wiwŏnhoe, 1986).

9 Ch'oe Soja, Myŏng Ch'ǒng sidae Chung Han kwan'gyesa yŏn'gu (Ihwa Yŏja Taehakkyo Ch'ulp'anbu, 1997); "Horan kwa Chosŏn ŭi dae Myŏng Ch’ŏng kwan'gye ŭi pyŏnjil: Sadae kyorin ŭi munje rŭl chungsim ŭro," Idea sawŏn 12 (1975); “Ch’ŏngjŏng esŏ ŭi Sohyŏn seja," Chŏn Haejong paksa hwagap kinyŏm sahak nonch'ong (Ilchogak, 1979); "Chungguk ch'ŭk esŏ pon Chŏngmyo Pyŏngja yangyŏk," Ihwa yŏdae nonch'ong 57 (1990); "Ch’ŏng kwa Chosŏn: Myŏng Ch'ŏng kyoch'egi Tong Asia ŭi kukche chilsŏ esŏ," Ihwa sahak yŏn'gu 22 (1994); Ch'ŏng kwa Chosŏn: Künse Tong Asia üi sangho insik (Hyean, 2005).

10 Kim Chongwŏn, Künse Tong Asia kwan'gyesa yŏn'gu: Cho Ch'ŏng kyosŏp kwa Tonga samguk kyoyŏk ŭl chungsim ŭro (Hyean, 1999); Kim Chongwŏn and Yi Yangja, Chosŏn hugi taeoe kwan'gye yŏn'gu (Hanul, 2009).

11 Han Myŏnggi, "Chŏngmyo Pyŏngha horan kwa Tong Asia chilsŏ," in Cho Pyŏnghan and others, Chŏnjaeng kwa Tongbuga ŭi kukje chilsŏ (Ilchogak, 2006); Yi Samsŏng, "Myŏng Ch'ŏng kyoch'e ŭi Tong Asia wa Hanbando ŭi chŏnjaeng," in Tong Asia ŭi chŏnjaeng kwa p'yŏnghwa (Han'gilsa, 2009); Noh Yŏnggu, “17segi chŏn'gi Tong Asia p'aekwŏn kyoch'e wa Pyŏngja horan,” in Chu Myŏnggŏn and others, Hanbando ŭi unmyŏng ŭl kyŏlchŏng han chŏnjaeng (Sejong Yŏn'guwŏn, 2014).

12 Han Myŏnggi, Chŏngmyo Pyŏngja horan kwa Tong Asia chilsŏ (P'urŭn yŏksa, 
public interest in early Manchu history has been such that a journalist published a book on Hongtaiji (洪太極, the han [emperor] of the Later Jin/Qing dynasty, also known as Taizong), who consolidated the empire after the death of his father Nurhaci. ${ }^{13}$

\section{Focus on Qing Political History}

Korean scholars used to subscribe to the idea of a continuation of socioeconomic homogeneity during the dynastic change from the Ming to the Qing. The name of the scholarly association "Myŏng Ch'ŏng Sahakhoe" [Society for Ming-Qing Historical Studies] reflects precisely this tendency. However, there have appeared new perspectives that attempt to separate and find "discontinuity" between the Ming and Qing periods. Im Kyesun led the approach as she wrote a Qing history based on works by both Korean and foreign scholars. ${ }^{14}$ More recently, Ku Pŏmjin published a book on Qing history based on this new approach. ${ }^{15}$

One can attribute the increased scholarly interest on the Qing period to the "New Qing History" in the US. A number of scholars educated in the US introduced the New Qing History through review articles. Translation and publication in Korea of several important works by Western scholars stimulated academic debate. ${ }^{16}$ Moreover, the Chinese state sponsored projects on the compilation of Qing history also intensified scholarly

2009); [Yŏksa p'yŏngsol] Pyŏngja horan 1 · (P’urŭn yŏksa, 2013 \& 2014).

13 Chang Hansik, Orangk'ae Hongtaiji ch'ónha rŭl ŏtta (Sansuya, 2015).

14 Im Kyesun, Ch'ŏngsa: Manjujok i t'ongch'i han Chungguk (Sinsŏwŏn, 2000).

15 Ku Pŏmjin, Ch’ŏng nara: Kimera ŭi cheguk (Minŭmsa, 2012).

16 They include Evelyn Rawski's Last Emperors: A Social history of Qing Imperial institutions (University of California Press, 1988), Pamela K. Crossley's The Manchus (Blackwell, 2002), Mark C. Elliott's The Manchu Way: The Eight Banners and Ethnic Identity in Late Imperial China (Stanford University Press, 2001), and Peter Perdue's China Marches West: The Qing Conquest of Central Eurasia (Belknap Press, 2005). 
attention. ${ }^{17}$ We now have several doctoral dissertations on Qing politics and institutions, ${ }^{18}$ topics that had rarely received much attention previously. We can expect more research on Qing political history in the near future.

\section{Studies on the Identity of the Manchus and Manchuria}

Another research trend has been a focus on the separate historical identity of Manchuria and its peoples. Kim Kujin tried to identify the characteristics of Jurchen society, ${ }^{19}$ and later scholars wrote dissertations that examined the Later Jin/Qing before the Manchus entered China in $1664 .{ }^{20}$ Sŏ Chŏnghŭm published several articles on the Eight Banner System and other topics, ${ }^{21}$ and Yu Chiwŏn continued to work on the

17 Chŏng Hyejung and others, Chungguk ŭi Ch'öngsa kongjŏng yŏn'gu (Tongbuga Yŏksa Chaedan, 2008) ; Yu Changgŭn and others, Chungguk yǒksa hakkye ŭi Ch'ŏngsa yŏn'gu tonghyang: Han'guk kwallyŏn punya rŭl chungsim ŭro (Tongbuga Yŏksa Chaedan, 2009) ; Kim Hyŏngjong and others, Chungguk ŭi Ch'óngsa p'yŏnch'an kwa Ch'óngsa yŏn'gu (Tongbuga Yŏksa Chaedan, 2010).

18 Song Miryŏng, “Ch’ŏng chunggi Kun'gich'ŏ yŏn'gu: Ongjŏng Kŏllyungje ŭi Kun'gich’ŏ unyong kwa hwangje kwŏllyok ŭi han'gye,” Ph.D. diss., Ihwa Yŏja Taehakkyo, 2003 [this dissertation was published as a monograph in 2005] ; Yi Hun, "17 18 segi Ch’ŏngjo ŭi Manju chiyŏk e taehan chŏngch'aek kwa insik: Kŏllyunggi Manjujok ŭi wigi wa kwallyŏn hayŏ ," Ph.D. diss., Koryŏ Taehakkyo, 2013; Yi Sŏnae, "Ch'ŏng ch'ogi oebon [tulegi golo] hyŏngsŏng kwajŏng kwa Ibŏnwŏn,” Ph.D. diss., Koryŏ Taehakkyo, 2014.

19 Kim Kujin, “13c 17c Yŏjin sahoe ŭi yŏn'gu: Kŭm myŏlmang ihu Ch’ŏng kŏn'guk ijŏn kkaji Yŏjin sahoe ŭi chojik ŭl chungsim ŭro," Ph.D. diss., Koryŏ Taehakkyo, 1989.

20 Noh Kishik, "Hu Kŭm sigi Manju wa Monggo kwan'gye,” Ph.D. diss., Koryŏ Taehakkyo, 1999; Cho Pyŏnghak, "Ipkwanjŏn Hu Kŭm ŭi Mongol mit Manjujok t'onghap e kwanhan yŏn'gu," Ph.D. diss., Chungang Taehakkyo, 2002.

21 Sŏ Chŏnghŭm, "P'algije wa Manjujok ŭi Chungguk chibae: P'algije ŭi hŭngsoe wa Manju chŏnggwon ŭi sojang," Manju yŏn'gu 3 (2005). 
capital and shamanism during the Later Jin period. ${ }^{22}$

Again, these efforts have been stimulated by the introduction and translations of foreign scholarship. ${ }^{23}$ Other works show a Manchucentered approach to the study of the Manchurian region or an interdisciplinary approach to Manchurian culture. ${ }^{24}$ One scholar focused on separate identity of the Yodong (遼東) in its historical connections with Korean and Chinese history. ${ }^{25}$ Another study also took the Modern Liaodong region as the center and examined its relations with the "peripheries." 26

\section{Greater Utilization of Korean Historical Sources and Manchu Documents}

The final research trend is a greater utilization of Korean historical sources, especially after extensive digitalization of important source materials. Scholars have been aware of the importance of the Chosŏn wangjo sillok for the study of Jurchen and Manchu history, but it was

22 Yu Chiwŏn, "Han'gung esŏ Hwanggung ŭro: Simyang kokung ŭi munhwajŏk hamŭi," Chungguksa yŏn'gu 57 (2008); "Pyŏnsŏng esŏ tosŏng ŭro," Tongyang sahak yŏn'gu 105 (2008).

23 Chŏng Pyŏngjun, Chungguk hakkye ǔi pukbang minjok kukka yŏn'gu (Tongbuga Yŏksa Chaedan, 2008); Yun Yŏngin and others, 10 18 segi pukbang minjok kwa chŏngbok wangjo yŏn'gu (Tongbuga Yŏksa Chaedan, 2009); Yun Yŏngin and others, Oeguk hakkye ŭi chŏngbok wangjo yŏn'gu sigak kwa ch'oegun tonghyang (Tongbuga Yŏksa Chaedan, 2010); Translation of Thomas Barfield's Perilous Frontier: Nomadic Empires and China, 221 BC to AD 1757 (Cambridge MA \& Oxford, UK: Blackwell, 1989) by Yun Yŏngin (Tongbuga Yŏksa Chaedan, 2009).

24 Manju: Kŭ ttang, saram, kŭrigo yŏksa (Koguryŏ Yŏn'gu Chaedan, 2005); Han Sŏkchŏng and No Kishik, eds., Manju, Tong Asia yunghap ŭi konggan (Somyŏng Ch'ulp'an, 2008); Manju iyagi (Tongbuga Yŏksa Chaedan, 2013).

25 Kim Han'gyu, Yodongsa (Munhak kwa Chisŏngsa, 2004).

26 Yu Chaech'un and others, Künse Tong Asia wa Yodong (Ch'unch'ŏn: Kangwŏn Taehakkyo Ch'ulp'anbu, 2011). 
difficult to search a vast amount of information written in classical Chinese. Recent digitalization of the sillok, along with Korean translations, made these sources very accessible for research. ${ }^{27}$ More historical sources such as Süngjŏngwŏn ilgi (承政院日記, Journal of the Royal Secretariat) have now been translated and digitalized. ${ }^{28}$

In a very encouraging sign, we now have translations of a number of source materials on pre-1644 Manchu history. Two are especially important in the study of Manchus of this crucial period in the early seventeenth century. One is the Simyang ilgi (潘陽日記, Shenyang Diaries), the record regarding Prince Sohyŏn who was being held in Shenyang as a hostage. Another is the Simyang changgye (瀋陽狀啓), a collection of correspondence between Shenyang and the Chosŏn court. ${ }^{29}$ Translations of diaries and the reports by Chosŏn envoys [collectively known as the "Travelogues of Korean Envoys to China", 燕行錄] also contributed to the boom in the Manchu studies. ${ }^{30}$ Compilations of massive materials of records of Chosŏn envoys enabled a more comprehensive and detailed study of the Chosŏn view of the Manchu Qing.

Finally, a very important development has been the greater utilization of documents in the Manchu language and script. Kim Tuhyŏn collated the entries in the Old Manchu Archives (舊滿洲檔) and the Old Manchu Chronicles (滿文老檔). ${ }^{31}$ While there have already been translations of

$27 \mathrm{http}: / /$ sillok.history.go.kr/main/main.jsp.

$28 \mathrm{http}: / / \mathrm{db}$.itkc.or.kr/itkcdb/mainIndexIframe.jsp.

29 There are three recent translations of this work: Sejong taewang kinyŏm saŏphoe, ed., Kugyŏk Simyang changgye (Sejong taewang kinyŏm saŏphoe, 1999 2000); Chŏng Hayŏng and others, Simyang changgye: Simyang esŏ on p'yŏnji (Ch'angbi, 2008); Kim Namyun, Simyang changgye: 1637 1643 nyŏn Simyang esŏ ŭi kin'gŭp pogo (Akanet, 2014).

30 Im Kijung, ed., Yŏnhaengnok chŏnjip (Tongguk Taehakkyo Ch’ulp'anbu, 2001); Im Kijung and Fuma Susumu, eds., Yŏnhaengnok chŏnjip Ilbon sojangp’yŏn (Tongguk Taehakkyo Han'guk Munhak Yŏn'guso, 2001); Im Kijung, ed., Yŏnhaengnok sokchip (Sangsŏwŏn, 2008). 
important source materials in Japanese, Chinese and other languages, we now have new Korean translations of the Old Manchu Chronicles, Old Manchu Archives, the Veritable Records of the Manchus (滿洲實錄) and the Diary of Dzengsheo have also been published. ${ }^{32}$ We now have informal seminars and study groups that focus on reading and translating original Manchu documents. Scholars of Korean linguistics have long utilized Manchu documents, but historians have now started to take note of the importance of Manchu documents.

\section{Conclusion}

It was during the reign of Qianlong emperor that the Manchus began the study of their own people and their homeland of Manchuria. In modern times, Japanese scholars were the first to study Manchurian history systematically, partly to support the imperialist project on Manchuria. Still, Japanese studies on Manchu history and culture were significant, especially their discovery and utilization of Manchu documents. Japanese scholarship continues to produce important works on Manchu studies and the puppet state of Manchukuo.

Modern Chinese studies of Manchuria began as an attempt to counter Japanese colonial history and now continue as "Manchu Studies" (滿學) and “the Borderland history of the Northeast" (東北邊疆史). China's historical experience of losing Manchuria to Japanese imperialist aggression and semi-colonial modernity has strongly influenced current

31 Kim Tuhyŏn, Manmun nodang kwa Ku Manjudang taejop'yo: T'aejojo (Ulsan Taehakkyo Ch'ulp'anbu, 2010).

32 Ch'oe Tonggwŏn, Ku Manjudang 1: Hwangjadang (Pogosa, 2007) ; Koryŏ Taehakkyo Minjok Munhwa Yŏn'guwŏn Manjuhak Sentŏ Manju Sillok Yŏkchuhoe, Manju sillok yǒkchu (Somyŏng Ch'ulp'an, 2014) ; Ch’oe Tonggwŏn and others, Manju p'algi Chŭngsu ŭi ilgi (Pangmunsa 2012). This "Diary of Dzengsheo" had been translated into English by Nicola Di Cosmo and published as The Diary of a Manchu Soldier in Seventeenth-century China (Routledge, 2006). 
studies of the borderland and ethnic groups based on a unified multi-ethic state theory. The Chinese government has been sponsoring the Northeast Project and Qing History compilation Project, but there remains some concern that the historical identity of the Manchus and Manchuria may be buried in the narrative of the unified history of the "Chinese nation."

Although Korean scholarship on Manchu history has had a late start, it has been developing lately. The recently established Center for Manchurian Studies at Korea University has been carrying out interdisciplinary research on history, culture, language, and literature under the leadership of its director Dr. Kim Seonmin. The Manchurian Studies Association was founded in 2001, and its members have been conducting various studies on Manchuria including international relations among imperialist powers, Japanese colonial control, Korean population in twentieth century Manchuria, and social and scientific aspects of Manchuria as a region, etc.

In the end, these research trends are closely connected to Korea's present situation and future prospects. From the division of Korea in 1945, the Republic of Korea was separated from Manchuria spatially for more than half century. However, within a couple of decades since the normalization of official relations between Korea and the People's Republic of China, we have witnessed exchange of people and trade between the two regions. There remain historical disputes, especially over the ancient state of Koguryŏ. However, we can expect Manchu studies in Korea to grow even more rapidly as Manchuria will play a crucial role in the future inter-Korean relations. 